\title{
Ripening and quality of 'Laetitia' plums following harvest and cold storage as affected by inhibition of ethylene action ${ }^{(1)}$
}

\author{
Luiz Carlos Argenta(2), Juliana Golin Krammes(2), Clarice Aparecida Megguer(2), \\ Cassandro Vidal Talamini Amarante ${ }^{(3)}$ and James Mattheis ${ }^{(4)}$
}

\begin{abstract}
The inhibition of ethylene action by 1-methylcyclopropene (1-MCP) extends shelf and storage life of many climacteric fruits. However, 1-MCP appears to have limited effects on stone fruit depending on specie and cultivar. The effects of 1-MCP on ripening and quality of 'Laetitia' plums were determined during ripening at $23^{\circ} \mathrm{C}$ following harvest and cold storage. Japanese plums (Prunus salicina, cv. Laetitia) were harvested at mature pre-climacteric stage, cooled to $2^{\circ} \mathrm{C}$ within 36 hours of harvest and then treated with $0,0.05,0.10,0.50$ or $1.00 \mu \mathrm{L} \mathrm{L}^{-1}$ of $1-\mathrm{MCP}$ at $1^{\circ} \mathrm{C}$ for 24 hours. Following treatment, fruits were either held at $23^{\circ} \mathrm{C}$ for 16 days or stored at $1^{\circ} \mathrm{C}$ for 50 days. Fruits were removed from cold storage at 10-day intervals and allowed to ripe at $23^{\circ} \mathrm{C}$ for five days. A delay of climacteric respiration and ethylene production by 1-MCP treatment during ripening following harvest and cold storage was associated to a slow rate of fruit softening. 1-MCP treatment also delayed the loss of titratable acidity and changes of flesh and skin color, whereas it had little or no effect on soluble solids content. 1-MCP effects were concentrationand storage duration-dependent and, generally, a saturation fruit response to 1-MCP occurred between 0.5 and $1.0 \mu \mathrm{L} \mathrm{L}^{-1}$. During ripening, 1-MCP treated fruits attained quality similar to that of controls. Results indicated that 1-MCP treatment may extend shelf life $\left(23^{\circ} \mathrm{C}\right)$ and storage life $\left(1^{\circ} \mathrm{C}\right)$ of 'Laetitia' plums by approximately six and 20 days, respectively.
\end{abstract}

Index terms: Prunus salicina, fruit pulps, firmness, shelf life, fruit, colour.

Efeitos da inibição da ação do etileno na maturação e qualidade de ameixas 'Laetitia' após a colheita e armazenagem refrigerada

Resumo - A inibição da ação do etileno pelo 1-metilciclopropeno (1-MCP) prolonga a vida de prateleira e de armazenagem de vários frutos climatérios. Entretanto, 1-MCP parece ter efeitos limitados em frutas de caroço dependendo da espécie e cultivar. Os efeitos do 1-MCP na maturação e qualidade de ameixas 'Laetitia' foram determinados durante a maturação a $23^{\circ} \mathrm{C}$ após a colheita e após a armazenagem refrigerada. Ameixas (Prunus salicina, cv. Laetitia) foram colhidas em estádio pré-climatério, resfriadas a $2^{\circ} \mathrm{C}$ em 36 horas da colheita e então tratadas com 1-MCP nas doses de $0 ; 0,05 ; 0,10 ; 0,50$ ou $1,00 \mu \mathrm{L} \mathrm{L}^{-1}$ a $1^{\circ} \mathrm{C}$ por 24 horas. Após o tratamento os frutos foram mantidos a $23^{\circ} \mathrm{C}$ por 16 dias ou armazenados a $1^{\circ} \mathrm{C}$ por 50 dias. Os frutos foram removidos da câmara de armazenagem refrigerada a cada 10 dias e então deixados a amadurecer a $23^{\circ} \mathrm{C}$, por cinco dias. O retardamento do climatério respiratório e da produção de etileno pelo tratamento 1-MCP durante a maturação após a colheita e após a armazenagem refrigerada foi associado à redução da taxa de amolecimento da polpa dos frutos. O tratamento 1-MCP também retardou a perda da acidez titulável e as mudanças de coloração da polpa e da epiderme, mas teve pequeno ou nenhum efeito sobre o teor de açúcares solúveis. Os efeitos do 1-MCP dependeram da sua concentração e do período de armazenagem dos frutos e, normalmente, a dose de saturação das respostas dos frutos ao 1-MCP ocorreu entre 0,5 e $1,0 \mu \mathrm{L} \mathrm{L}^{-1}$. Durante a maturação, ameixas tratadas com 1-MCP desenvolveram qualidade semelhante a dos frutos controle. Os resultados indicam que o tratamento 1-MCP pode estender a vida de prateleira $\left(23^{\circ} \mathrm{C}\right)$ e de armazenagem $\left(1^{\circ} \mathrm{C}\right)$ de ameixas 'Laetitia' por aproximadamente seis e 20 dias, respectivamente.

Termos para indexação: Prunus salicina, polpa de fruta, firmeza, prazo de validade, fruto, cor.

(1) Accepted for publication on August 18, 2003.

(2) Empresa de Pesquisa Agropecuária e Extensão Rural de Santa Catarina, Estação Experimental de Caçador, Caixa Postal 591, CEP 89500-000 Caçador, SC. E-mail: argenta@epagri.rct-sc.br, ju.golin@bol.com.br, cmegguer@hotmail.com
(3) Universidade do Estado de Santa Catarina, Centro de Ciências Agroveterinárias, Caixa Postal 281, CEP 88502-970 Lages, SC. E-mail: amarante@cav.udesc.br

(4) United States Department of Agriculture, Tree Fruit Research Laboratory, 1104 N. Western Av., 98801Wenatchee, WA. E-mail: mattheis@tfrl.ars.usda.gov 


\section{Introduction}

Most fresh plums marketed in Brazil are imported because local production is greatly limited by orchard diseases (Ducroquet \& Mondin, 1997; Ducroquet et al., 2001). Despite this constraint, profitable commercial orchards have been established in Southern Brazil after the introduction of new plum cultivars and integrated methods to prevent the main tree diseases (Ducroquet \& Mondin, 1997). As the plum production increases, new technologies for postharvest maintenance of fruit quality are required.

Laetitia (FFTRI, South Africa) is a Japanese plum cultivar fairly adapted to the Southern Brazilian climate, resistant to Xantomonas spot and moderately tolerant to leaf scald (Ducroquet et al., 2001). Improving postharvest life would increase the marketing period of this late season cultivar.

Plums have a short postharvest life compared to other climacteric temperate fruits such as apples and pears (Kader, 1992). Low temperature is the most effective mean to delay postharvest ripening and deterioration of plums and to schedule ripening according to marketing needs (Kader \& Mitchell, 1989; Mitchell \& Kader, 1989a). However, many plum cultivars, such as Laetitia, might develop chilling injury, depending on storage temperature and span (Mitchell \& Kader, 1989a; Taylor 1996; Abdi et al., 1997a).

Cold storage, under modified atmosphere (Couey, 1965; Crouch, 1998) and controlled atmosphere (CA) (Mitchell \& Kader, 1989b; Truter \& Combrink, 1997) improves flesh firmness and ground color retention and reduces shrivel in some plum cultivars. However, CA does not prevent chilling injury and may reduce the flavor after long-term storage, limiting its commercial use to extend plums storage life (Eksteen et al., 1986; Mitchell \& Kader, 1989b; Truter \& Combrink, 1997).

Removal of ethylene from the environment surrounding stone fruits might improve storage, because ripening is regulated by ethylene (Kader \& Mitchell, 1989). However, most methods to remove ethylene from commercial storage rooms have normally been ineffective since many fruits are harvested in advanced ripening stage, when endogenous ethylene reaches 1 to $3 \mu \mathrm{L} \mathrm{L}^{-1}$ that is high enough to trigger stone fruit ripening (Mitchell \& Kader, 1989a).
Inhibition of ethylene action by 1-methylcyclopropene (1-MCP) (Sisler \& Serek, 1997) effectively delays ripening and extends postharvest life of climacteric fruits such as banana, apple, and tomato (Blankenship \& Dole, 2003). The use of 1-MCP also reduces ethylene production and improves quality of stone fruits such as plum, apricot, nectarine, and peach during shelf life (Abdi et al., 1998; Fan et al., 2000; Dong et al., 2001a; Fan et al., 2002). However, 1-MCP may have different effects on ripening and quality attributes of stone fruits after cold storage. Treatment with 1-MCP at harvest extends cold storage life of plum (Dong et al., 2002) and apricot, cultivar Perfection (Fan et al., 2000), whereas it can increase chilling injury in some cultivars of nectarine (Dong et al., 2001a), apricot (Dong et al., 2002) and peach (Fan et al., 2002) after long-term cold storage.

The objective of this work was to determine the effects of 1-MCP on ripening and quality attributes of 'Laetitia' plum at room temperature following harvest and cold storage.

\section{Material and Methods}

\section{Fruit, 1-MCP treatment, ripening, and storage conditions}

'Laetitia' plums (Prunus salicina) of uniform size $(102 \pm 4 \mathrm{~g})$ were harvested from an experimental orchard in Central Santa Catarina State at mature pre-climacteric stage on February 2002. The fruits were harvested from selected 7 to 8 year-old trees of 'Laetitia' plums grafted on peach seedlings rootstock. The fruits were cooled to $2^{\circ} \mathrm{C}$ within 36 hours of harvest and then treated with $0,0.05$, $0.10,0.50$ or $1.00 \mu \mathrm{L} \mathrm{L}^{-1}$ of 1-MCP (1-methylcyclopropene) at $1^{\circ} \mathrm{C}$ for 24 hours in a $340 \mathrm{~L}$ container (made of PVC, with a plastic glass lid and a sealing rubber belt). The 1-MCP was generated as a gas outside the treatment container by mixing SmartFresh ${ }^{\mathrm{TM}}$ powder (AgroFresh Inc., 0.14\% a.i.) and water in a $500 \mathrm{~mL}$ flask at $35^{\circ} \mathrm{C}$. The $1-\mathrm{MCP}$ gas was pumped from the flask into the container for 10-15 min via a closed loop, as described by Fan et al. (2002). Following treatment, fruits were placed on plastic trays and either maintained at $23^{\circ} \mathrm{C}(75 \pm 8 \% \mathrm{RH})$ for 16 days or stored at $1{ }^{\circ} \mathrm{C}(80 \pm 5 \% \mathrm{RH})$ for 20 to 50 days. Fruit samples were removed from cold storage at 10-day intervals and allowed to ripe at $23^{\circ} \mathrm{C}$ for five days. During ripening, ethylene and respiration were measured daily while fruit 
firmness, titratable acidity (TA), soluble solids content (SSC) and fruit color were assayed every four days following harvest, and after five days following cold storage.

\section{Ethylene production, respiration, and 1-MCP determination.}

For ethylene production and respiration analyses, fruits were placed in $4 \mathrm{~L}$ glass jars maintained at $23^{\circ} \mathrm{C}$ and supplied with compressed ethylene free air, at $100 \mathrm{~mL} \mathrm{~min}^{-1}$. Effluent air was analyzed for $\mathrm{CO}_{2}$ and ethylene concentrations by a gas chromatograph equipped with a methanizer, two flame ionization detectors, a stainless steel column (with $1.0 \mathrm{~m}$ and $2.0 \mathrm{~mm}$ i.d.) packed with 80 to 100 mesh Poropak Q (for $\mathrm{CO}_{2}$ ) and a glass column (with $0.6 \mathrm{~m}$ and $3.2 \mathrm{~mm}$ i.d.) packed with 80 to 100 mesh Poropak Q (for ethylene). Oven, detectors, methanizer and injector temperatures were set at $45,120,300$ and $110^{\circ} \mathrm{C}$, respectively.

Headspace concentration of 1-MCP in the treatment containers was measured 10-15 min after fruit treatment started, using the same method used for ethylene analysis, except that 1-MCP gas was used as standard and that the oven temperature was $90^{\circ} \mathrm{C}$. Gas flows for $\mathrm{N}_{2}, \mathrm{H}_{2}$ and air were 70,30 and $300 \mathrm{~mL} \mathrm{~min}^{-1}$, respectively for all ethylene, $\mathrm{CO}_{2}$ and 1-MCP analyses.

\section{Analysis of fruit quality}

Firmness was measured on two pared cheek sides of each fruit with a pressure tester fitted with an $8 \mathrm{~mm}$ (diameter) probe. Two flesh slices were taken from the opposite sides of each fruit and four slices were combined to prepare a juice sample on a Champion juicer. The SSC (soluble solids content) and TA (titratable acidity) were assayed for each freshly prepared juice sample. The SSC was measured using a digital refractometer and TA was determined by titrating $5 \mathrm{~mL}$ of juice with $0.1 \mathrm{~N} \mathrm{NaOH}$ to pH 8.2 using an autotitrator. Skin and flesh color, measured as hue angle and lightness (L) (Hunter \& Harold, 1987), were assayed using a chromameter. Flesh color was measured on the same pared surface used for firmness assessment. Fruits were then cut through equatorial axis and the mesocarp visually assessed for internal disorders and decay as clear (1) or affected (2).

\section{Experimental design and statistical data analysis}

The experiment followed a completely randomized design with 21 fruits per treatment and storage duration combination. There were three replicates of seven fruits for analysis of ethylene production and respiration, 21-fruit replicates for analysis of fruit firmness and color and five replicates of four fruits for analysis of SSC and TA The data were subjected to analysis of variance using SAS (SAS Institute, Raleigh, USA). The least significant difference (LSD) between treatment means was assessed by Fisher's least significant difference test $(\alpha=0.05)$. Unless otherwise mentioned, only the significant $(\mathrm{P}<0.05)$ effects of ripening and storage period were discussed.

\section{Results and Discussion}

\section{Fruit ripening and quality following harvest}

Both $\mathrm{CO}_{2}$ and ethylene production by control fruit increased $(\mathrm{P}<0.05)$ from a minimum level to a peak, then declined during ripening at $23^{\circ} \mathrm{C}$ (Figure 1 ). The 1-MCP treatment delayed the rise of both respiration and ethylene production; ethylene production increased $(\mathrm{P}<0.05)$ from the first to sixth day in control fruits, from the sixth to ninth in fruit treated with 1-MCP at $0.05 \mu \mathrm{L} \mathrm{L}^{-1}$ and from the eighth to eleventh in fruit treated with 1 -MCP at 0.5 or $1 \mu \mathrm{L} \mathrm{L}^{-1}$. The maximum rate of ethylene production was not affected by 1-MCP at lowest concentration but it was slightly reduced by $1-\mathrm{MCP}$ at 0.5 or $1 \mu \mathrm{L} \mathrm{L}^{-1}$.

Maximum respiration rates were detected between five and seven days ripening in control fruits and between nine and 13 days ripening in treated fruits regardless of 1-MCP concentration. Differences in respiration rates among 1-MCP concentrations were significant only after six and eight days of ripening, when fruits treated with the lowest concentration exhibited higher respiration than fruits treated with the highest concentration.

Firmness and titratable acidity (TA) decreased $(\mathrm{P}<0.05)$ during fruit ripening (Figure 2). Flesh color changed from orange to dark-red while skin color changed from bright red to purple, as indicated by the reduction of the hue angle and lightness. Fruit treated with 1-MCP exhibited lower rates of softening, TA loss and color change relative to untreated fruit (Figure 2). Plums treated with 0.5 or $1.0 \mu \mathrm{L} \mathrm{L}^{-1} 1$-MCP were $7-10 \mathrm{~N}$ firmer and had approximately $34 \%$ higher TA than control fruits between four and 10 days ripening.

'Laetitia' plum has a climacteric pattern of respiration and ethylene production, which is 
associated with a quick fruit softening during ripening at $23^{\circ} \mathrm{C}$ following harvest (Figures 1 and 2). This ripening behavior is characteristic to most plum cultivars (Kader \& Mitchell, 1989). However, other cultivars, termed as suppressed-climacteric (Abdi et al., 1997b) or very slow-ripening (Crisosto, 1999), exhibit a maximum ethylene production 15 to 500 fold lower and a longer shelf life than typical climacteric cultivars (Abdi et al., 1997b; 1998). Generally, plums are highly perishable and, depending on cultivar, may soften 3.5 to $9.0 \mathrm{~N}$ a day at $25^{\circ} \mathrm{C}$ (Crisosto, 1999). The delay of climacteric respiration and ethylene production by 1-MCP treatment leads to a slow rate of plum softening (Dong et al., 2001b, 2002) (Figures 1 and 2).

Fruit softening is the most sensitive to ethylene ripening-related process (Lelièvre et al., 1997) and, a suitable predictor of potential shelf life for plum when

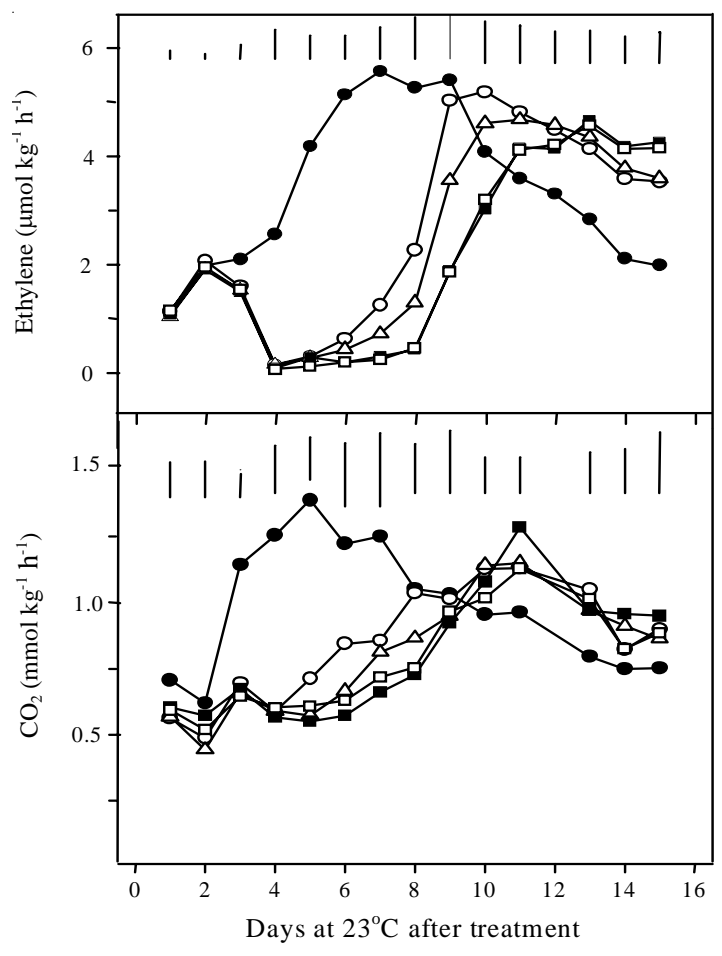

Figure 1. Ethylene and $\mathrm{CO}_{2}$ production by 'Laetitia' plums treated with $0(\mathbf{O}), 0.05(\bigcirc), 0.1(\Delta), 0.5(\mathbf{\square})$ and $1.0 \mu \mathrm{L} \mathrm{L}^{-1}(\square)$ 1-methylcyclopropene at harvest and then maintained at $23^{\circ} \mathrm{C}$ for 16 days. Bars represent $\mathrm{LSD}_{0.05}$ between treatment means. decay and chilling injury are not limiting factors (Kader \& Mitchell, 1989). Plums that reach flesh firmness of $9 \mathrm{~N}$ are considered ripe and 'ready to eat' (Crisosto, 1999). The 'ready to eat' ripeness was reached between the $4^{\text {th }}$ and $7^{\text {th }}$ day by the control and the $10^{\text {th }}$ and $13^{\text {th }}$ day by fruit treated with 1 -MCP at 0.50 or $1.00 \mu \mathrm{L} \mathrm{L}^{-1}$ indicating that 1-MCP treatment may extend shelf life following harvest (at $23^{\circ} \mathrm{C}$ ) of 'Laetitia' plum by approximately six days (Figure 2 ).

The 1-MCP effects were concentration-dependent for firmness and for fruit color after seven and 10 days and for TA after seven days ripening. Depending on the storage period, fruits treated with $0.05 \mu \mathrm{L} \mathrm{L}^{-1}$ 1-MCP were softener, less acid and redder than fruits treated with 0.5 or $1 \mu \mathrm{L} \mathrm{L}^{-1} 1$-MCP. Over the ripening period, fruits treated with $1 \mu \mathrm{L} \mathrm{L}^{-1} 1$-MCP had similar quality compared to those treated with 0.1 and $0.5 \mu \mathrm{L} \mathrm{L}^{-1} 1$-MCP. The soluble solids content (SSC) increased $(\mathrm{P}<0.05)$ during the first four days ripening in controls and during the first four or seven days of ripening in fruits treated with 1-MCP. Treatment with 1-MCP only affected SSC after four days of ripening, however, it reduced $(\mathrm{P}<0.05)$ the SSC/TA ratio for fruits held at $23^{\circ} \mathrm{C}$ following harvest. When fruits reached the 'ready to eat' firmness, SSC/TA ratio was 11.8 in the control and 10.9 in fruit treated with $1-\mathrm{MCP}$ at 0.50 or $1.00 \mu \mathrm{L} \mathrm{L}^{-1}$.

\section{Fruit ripening and quality following cold storage}

Respiration and ethylene production by control and fruit treated with 1 -MCP increased $(\mathrm{P}<0.05)$ within five days ripening following cold storage (Figures 3 and 4). Maximum rates of ethylene and $\mathrm{CO}_{2}$ production at $23^{\circ} \mathrm{C}$ following cold storage were treatment and storage duration-dependent. Maximum rates of ethylene production in control declined continuously with prolonged storage period and 1-MCP delayed this loss of fruit ability to produce ethylene during ripening following cold storage (Figure 3). Maximum ethylene production by fruits treated with $1-\mathrm{MCP}$ at 0.05 and $0.5 \mu \mathrm{L} \mathrm{L}^{-1}$ occurred following 30 or 40 days $(\mathrm{P}<0.05)$ storage. Rates of ethylene produced by fruits treated with 1-MCP at 0.05 or $0.10 \mu \mathrm{L} \mathrm{L}^{-1}$ were lower than those of the control following 20 days of cold storage, but higher than those of the control following 30-50 days of 
cold storage (Figure 3). Rates of ethylene produced by fruits treated with $1-\mathrm{MCP}$ at 0.50 or $1.0 \mu \mathrm{L} \mathrm{L}^{-1}$ were lower than those of the control following 20 and 30 days of cold storage, similar to those of the control following 40 days of cold storage, and higher than those of the control following 50 days of cold storage.

Respiration rates on control following 20 and 30 days on storage were similar to or higher than those on fruit treated with 1-MCP, depending on ripening period and 1-MCP concentration (Figure 4).

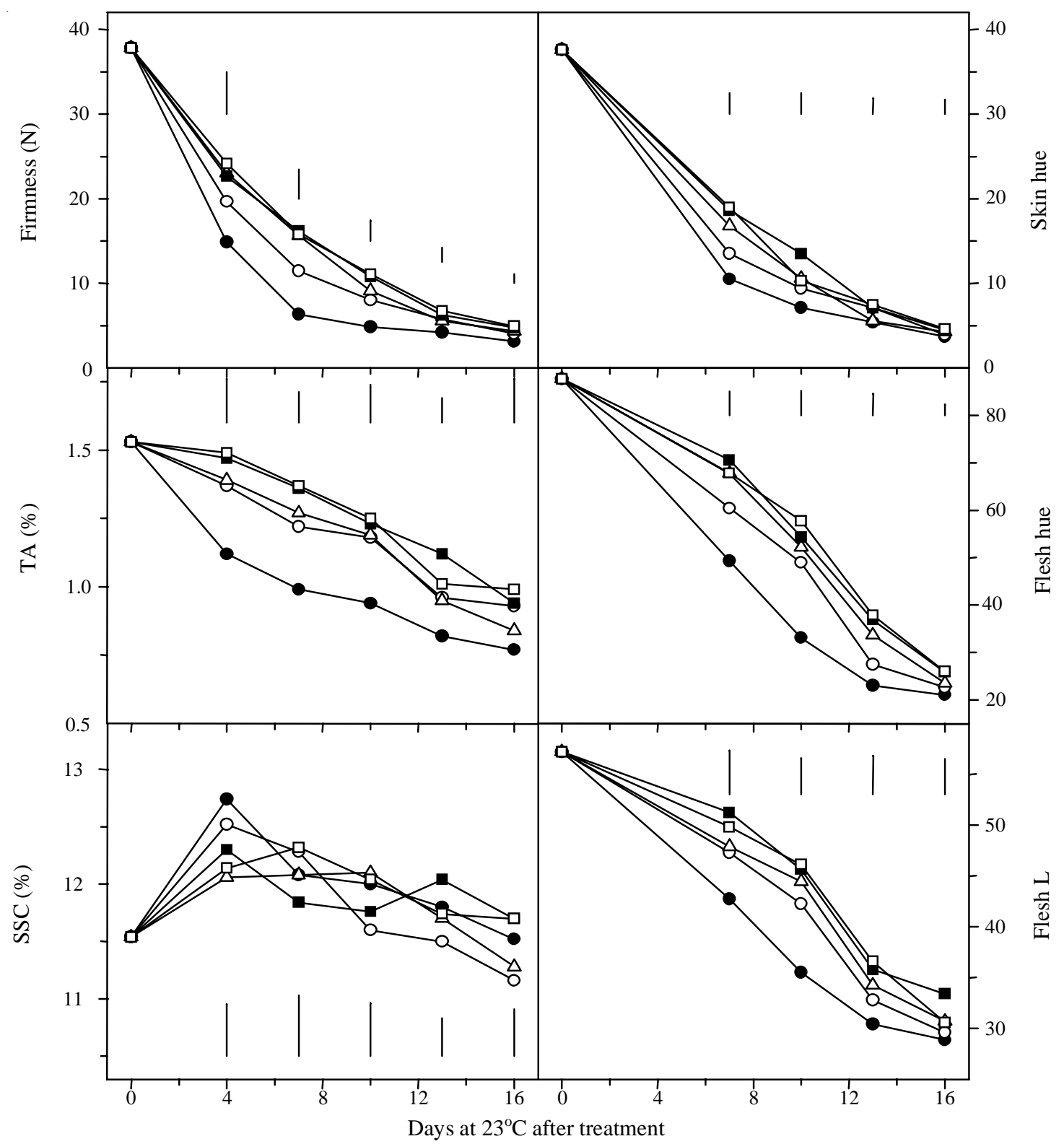

Figure 2. Changes of firmness, titratable acidity (TA), soluble solids content (SSC), skin and flesh hue, and flesh lightness $(\mathrm{L})$ in 'Laetitia' plums treated with $0(\mathbf{O}), 0.05(\mathrm{O}), 0.1(\Delta), 0.5(\mathbf{\square})$ and $1.0 \mu \mathrm{L} \mathrm{L}^{-1}(\square)$ 1-methylcyclopropene at harvest and then maintained at $23^{\circ} \mathrm{C}$ for 16 days. Bars represent $\mathrm{LSD}_{0.05}$ between treatment means. 
Respiration was not affected by 1-MCP treatments after 40 and 50 days storage regardless of the storage period. Maximum respiration rates were lower following 50 days ripening than at an earlier storage period, regardless of 1-MCP treatment.

Rates of ethylene production by stone fruits (Wang \& Adams, 1982; Brecht \& Kader, 1984; Valero et al., 1997), as well as by apple and pear (Knee et al., 1983), during ripening at warm temperature can be stimulated by prior exposure to low temperatures. However, prolonged storage at low temperatures may decrease fruit capacity to produce ethylene, which can be associated to the development of chilling injury (Wang \& Adams, 1982; Brecht \& Kader, 1984; Mollendorff \& De Villiers, 1988; Valero et al., 1997;
Fernandez-Trujillo et al., 1998; Dong et al., 2002). 'Laetitia' plums might develop chilling injury as a flesh gel breakdown, when stored at low temperatures (Truter \& Combrink, 1997; Crouch, 1998). However, no visual symptom of chilling injury on 'Laetitia' plums was detected in the present study.

The reduction of fruit ability to produce ethylene after prolonged cold storage period (Figure 3) might be attributed to the fruit over-ripen stage, as indicated by the very low fruit firmness after prolonged storage period (Figure 5). It has been suggested that the senescent-promoting action of ethylene, combined with prior exposure to a chilling temperature, may damage the enzymatic system that converts ACC to

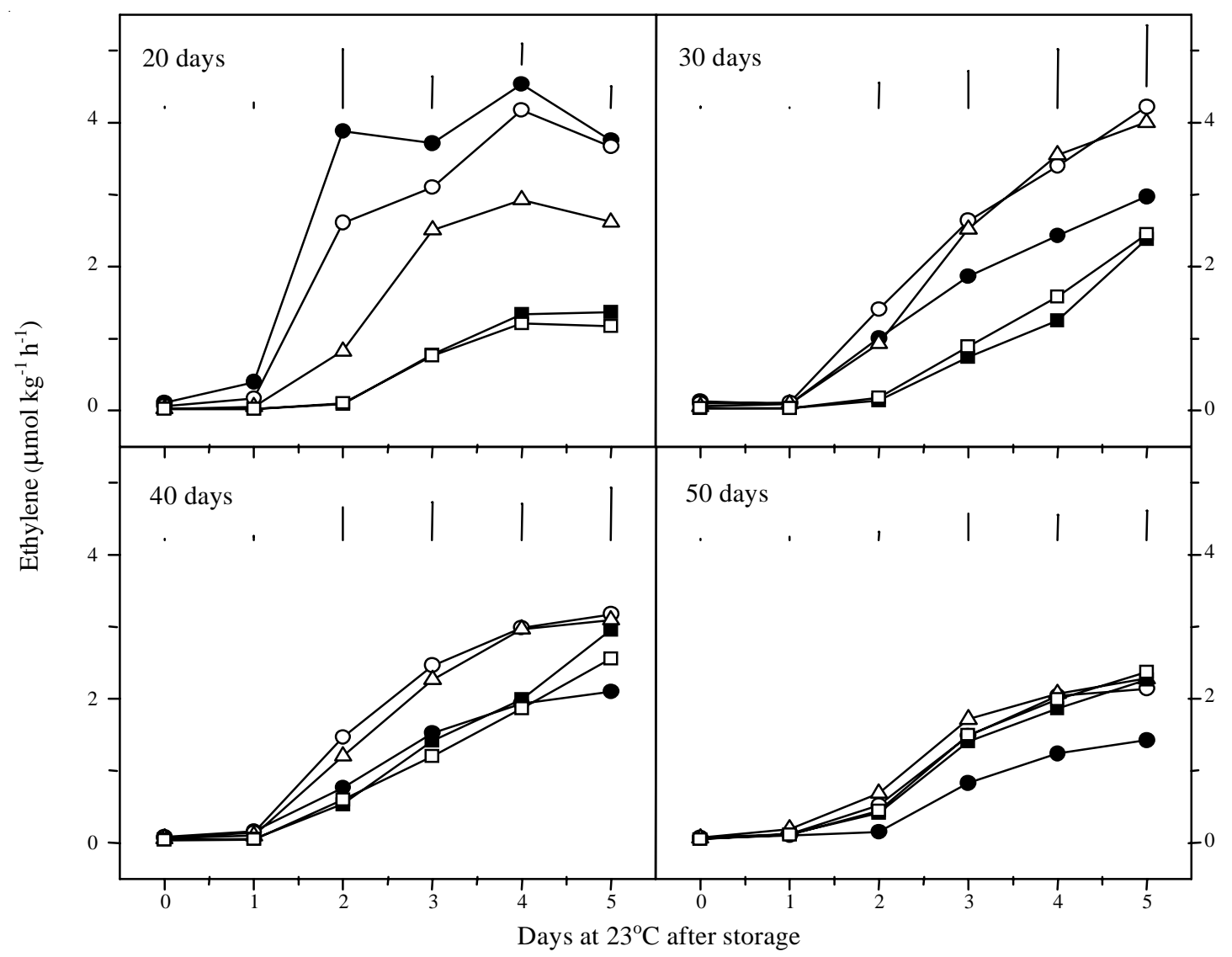

Figure 3. Ethylene production by 'Laetitia' plums treated with $0(\bigcirc), 0.05(\bigcirc), 0.1(\triangle), 0.5(\mathbf{\square})$ and $1.0 \mu \mathrm{L} \mathrm{L}^{-1}(\square)$ 1-methylcyclopropene at harvest, stored for $20-50$ days at $1{ }^{\circ} \mathrm{C}$ and then maintained at $23^{\circ} \mathrm{C}$ for 5 days. Bars represent $\mathrm{LSD}_{0.05}$ between treatment means. 
ethylene (Brecht \& Kader, 1984).

Most of softening, TA losses and changes of flesh and skin color on control fruit occurred during the first 10 days storage plus five days ripening (Figure 5). The 1-MCP delayed these changes in a concentration-dependent manner. Major effects of 1-MCP were detected at concentrations of 0.5 or $1 \mu \mathrm{L} \mathrm{L}^{-1}$, after ripening of the 10-30 day-storage fruits. Of all fruit color attributes, flesh hue was the most affected by 1-MCP.

Low temperature storage of 'Laetitia' plum delays beneficially ripening and 1-MCP treatment enhances low temperature effects on retention of fruit firmness (Figures 3-5). Flesh firmness of control fruits was $9 \mathrm{~N}$ ('ready to eat') after 10 days of storage at $1^{\circ} \mathrm{C}$ plus ripening while 1-MCP treated fruits reached $9 \mathrm{~N}$ of firmness after 30 days on storage plus ripening (Figure 5). These results indicate that 1-MCP treatment may extend storage life (at $1^{\circ} \mathrm{C}$ ) of 'Laetitia' plum by about 20 days. Beneficial effects of a single application of 1-MCP treatment on retention of fruit firmness have been previously demonstrated for other stone (Fan et al., 2000, 2002; Dong et al., 2002) and pome (Blankenship \& Dole, 2003) fruits.

SSC and TA are two of the most important quality indices for stone fruits (Crisosto, 1999). For plum, 1-MCP effects on TA appear to be cultivar and storage temperature dependent. Loss of TA is slowed by 1-MCP in typical climacteric plum cultivars, such as Laetitia (Figures 2 and 5) and Royal Zee (Dong

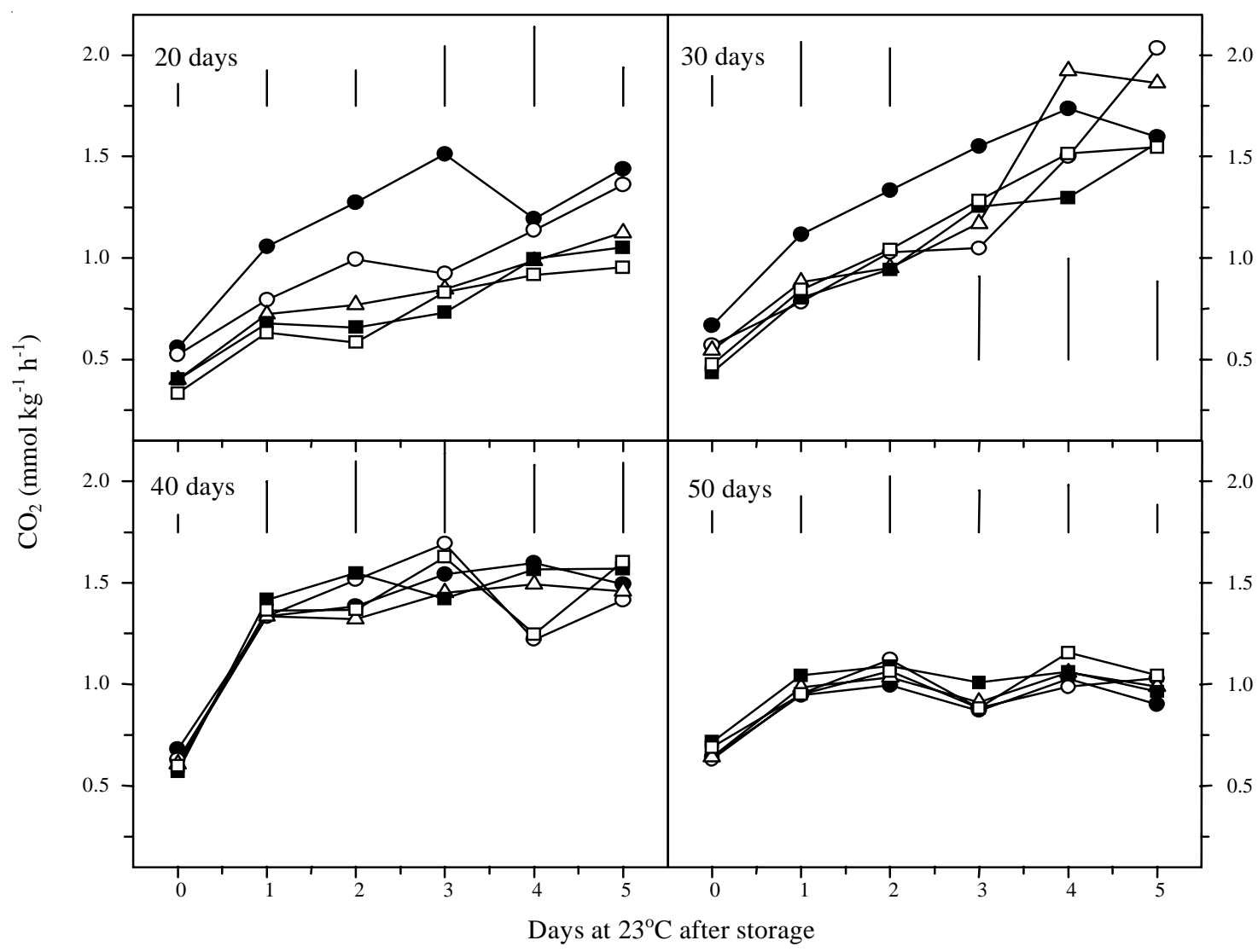

Figure 4. $\mathrm{CO}_{2}$ production by 'Laetitia' plums treated with 0 (O ), $0.05(\bigcirc), 0.1(\Delta), 0.5$ ) and $1.0 \mu \mathrm{L} \mathrm{L}-1(\square)$ 1-methylcyclopropene at harvest, stored for $20-50$ days at $1^{\circ} \mathrm{C}$ and then maintained at $23^{\circ} \mathrm{C}$ for 5 days. Bars represent $\mathrm{LSD}_{0.05}$ between treatment means. 
et al., 2002), but not in suppressed-climacteric type of plum, such as Red Rosa (Dong et al., 2001b). Impact of 1-MCP on retention of TA by 'Laetitia' was more evident during ripening at $23^{\circ} \mathrm{C}$ following harvest than after cold storage (Figures 2 and 5). SSC and SSC/TA ratio were not affected by 1-MCP treatment in cold stored fruit (Figure 5). Propylene treatment hastens the reduction of hue values in plum (Abdi et al., 1998) while 1-MCP treatment delays (Figures 2 and 5), indicating that color changes during

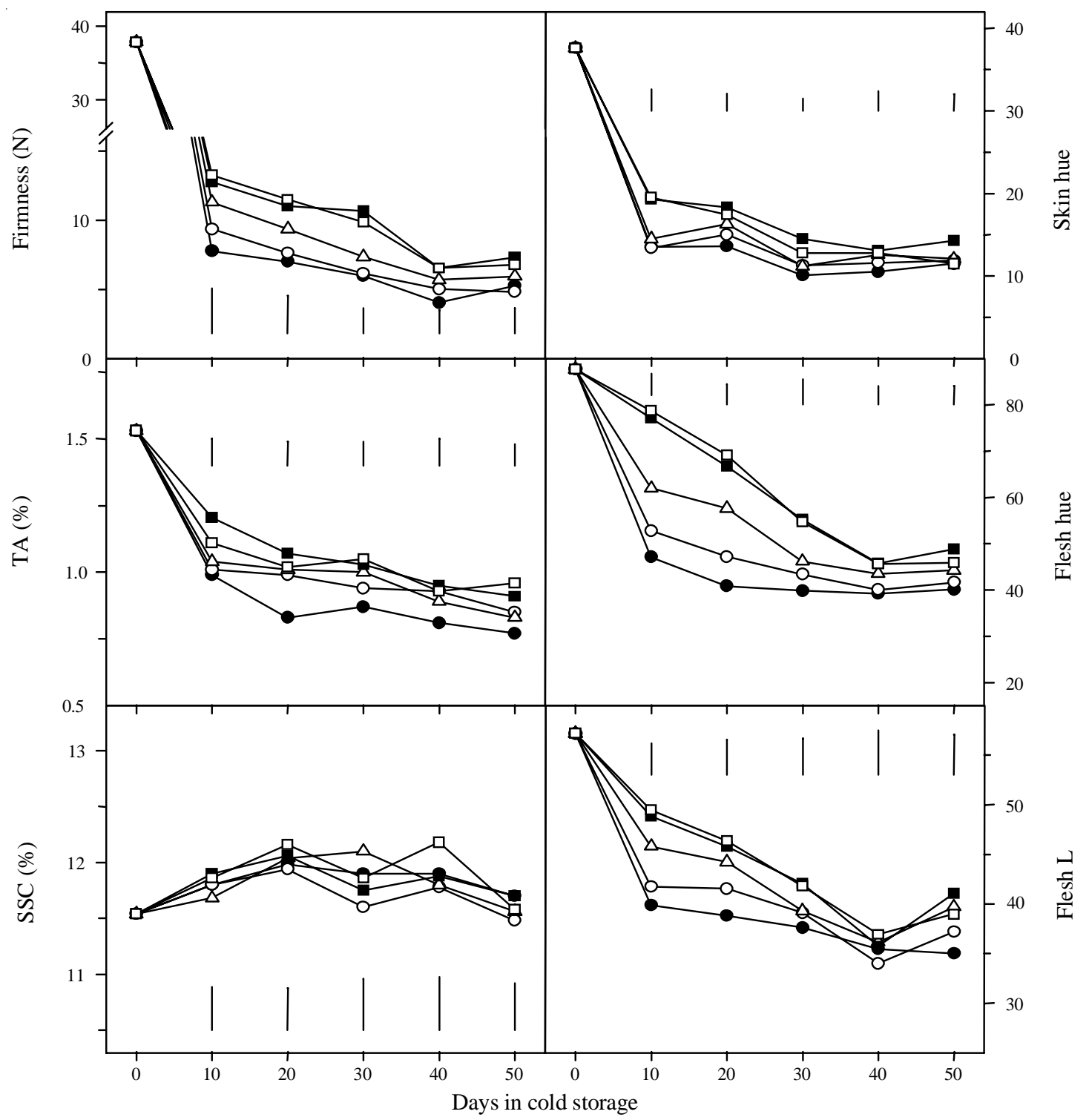

Figure 5. Changes of firmness, titratable acidity (TA), soluble solids content (SSC), skin and flesh hue, and flesh lightness $(\mathrm{L})$ in 'Laetitia' plums treated with $0(\mathbf{O}), 0.05(\mathrm{O}), 0.1(\Delta), 0.5(\boldsymbol{\square})$ and $1.0 \mathrm{~mL} \mathrm{~L}^{-1}(\square)$ 1-methylcyclopropene at harvest, stored for $20-50$ days at $1^{\circ} \mathrm{C}$ and then maintained at $23^{\circ} \mathrm{C}$ for 5 days. Bars represent $\mathrm{LSD}_{0.05}$ between treatment means. 
plum ripening is an ethylene-dependent process. However, in suppressed-climacteric types of plum, 1-MCP also delayed hue changes, and fruit attained full color without development of climacteric ethylene production (Abdi et al., 1998). Color changes can be either ethylene dependent or independent, according to the type of pigment involved and the fruit species (Lelièvre et al., 1997). In plums, the main color changes are based on accumulation of anthocinines (Wesche-Ebeling et al., 1996).

The 1-MCP effects on ethylene production and quality were concentration dependent, although there were little or no significant differences to the increase of 1-MCP concentration from 0.50 to $1.00 \mu \mathrm{L} \mathrm{L}^{-1}$, indicating a saturation response to 1-MCP.

\section{Conclusions}

1. 'Laetitia' plum has a rapid postharvest loss of fruit quality associated to a climacteric type of respiration and ethylene production.

2. The 1-MCP treatment delays the increase of climacteric respiration and ethylene production by plum during ripening following harvest and cold storage.

3. A fruit saturation response to 1-MCP occurs at 0.50-1.00 $\mu \mathrm{L} \mathrm{L}^{-1}$.

4. The 1-MCP treatment has the potential to control the ripening and extend shelf and storage life of plum.

5. The 1-MCP treatment extends shelf life (at $\left.23^{\circ} \mathrm{C}\right)$ following harvest and storage life $\left(\right.$ at $\left.1^{\circ} \mathrm{C}\right)$ of 'Laetitia' plum by approximately six and 20 days, respectively.

\section{Acknowledgement}

To Rhom and Haas Company, for financial support.

\section{References}

ABDI, N.; HOLFORD, P.; McGLASSON, W. B. Effects of harvest maturity on the storage life of Japanese type plums. Australian Journal of Experimental Agriculture, Collingwood, v. 37, p. 391-397, 1997a.

ABDI, N.; HOLFORD, P.; McGLASSON, W. B.; MIZRAHI, Y. Ripening behaviour and responses to propylene in four cultivars of Japanese type plums. Postharvest Biology and Technology, Amsterdam, v. 12, p. 21-34, 1997b.
ABDI, N.; McGLASSON, W. B.; HOLFORD, P.; WILLIAMS, M.; MIZRAHI, Y. Responses of climacteric and suppressed-climacteric plums to treatment with propylene and 1-methylcyclopropene. Postharvest Biology and Technology, Amsterdam, v. 14, p. 29-39, 1998.

BLANKENSHIP, S. M.; DOLE, J. M. 1-Methylcyclopropene: a review. Postharvest Biology and Technology, Amsterdam, v. 28, p. 1-25, 2003.

BRECHT, J. K.; KADER, A. A. Regulation of ethylene production by ripening nectarine fruit as influenced by ethylene and low temperature. Journal of the American Society for Horticultural Science, Alexandria, v. 109, p. 869-872, 1984.

COUEY, H. M. Modified atmosphere storage of 'Nubiana' plums. Proceedings of the American Society for Horticultural Science, Beltsville, v. 86, p. 166-168, 1965.

CRISOSTO, H. Optimum procedures for ripening stone fruit. In: UNIVERSITY OF CALIFORNIA (Davis, Unites States). Management of fruit ripening. Davis, 1999. p. 28-30S.

CROUCH, I. J. Effect of modified atmosphere packaging (MAP) on control of shrivel and overall quality of 'Laetitia' plums. Acta Horticulturae, Wellington, v. 464, p. 393396, 1998.

DONG, L.; LURIE, S.; ZHOU, H. Effect of 1-methylcyclopropene on ripening of 'Conino' apricots and 'Royal Zee' plums. Postharvest Biology and Technology, Amsterdam, v. 24, p. 135-145, 2002.

DONG, L.; ZHOU, H.; SONEGO, L.; LERS, A.; LURIE, S. Ethylene involvement in the cold storage disorder of 'Flavortop' nectarine. Postharvest Biology and Technology, Amsterdam, v. 23, p. 105-115, 2001a.

DONG, L.; ZHOU, H. W.; SONEGO, L.; LERS, A.; LURIE, S. Ripening of 'Red Rosa' plums: effect of ethylene and 1-methylcyclopropene. Australian Journal of Plant Physiology, Collingwood, v. 28, p. 1039-1045, 2001b.

DUCROQUET, J. P. H. J.; ANDRADE, E. R.; HICKEL, E. R. A escaldadura das folhas da ameixeira em Santa Catarina. Florianópolis: Epagri, 2001. 55 p. (Boletim Técnico, 118).

DUCROQUET, J. P. H. J.; MONDIN, V. P. Cadeias produtivas do Estado de Santa Catarina: pêssego e ameixa. Florianópolis: Epagri, 1997. 73 p. (Boletim Técnico, 80). 
EKSTEEN, G. J.; VISAGIE, T. R.; LASZLO, J. C. Controlled-atmosphere storage of South African grown nectarines and plums. Deciduous Fruit Grower, Bellville, v. 36, p. 128-132, 1986.

FAN, X.; ARGENTA, L. C.; MATTHEIS, J. P. Inhibition of ethylene action by 1-methylcyclopropene prolongs storage life of apricots. Postharvest Biology and Technology, Amsterdam, v. 20, p. 135-142, 2000.

FAN, X.; ARGENTA, L.; MATTHEIS, J. P. Interactive effects of 1-MCP and temperature on 'Elberta' peach quality. HortScience, Alexandria, v. 37, p. 134-138, 2002.

FERNANDEZ-TRUJILLO, J. P.; CANO, A.; ARTES, F. Physiological changes in peaches related to chilling injury and ripening. Postharvest Biology and Technology, Amsterdam, v. 13, p. 109-119, 1998.

HUNTER, R. S.; HAROLD, R. W. The measurement of appearance. $2^{\text {nd }}$ ed. New York: Wiley \& Sons, 1987. $411 \mathrm{p}$.

KADER, A. A. Postharvest biology and technology: an overview. In: KADER, A. A. (Ed.). Postharvest technology of horticultural crops. Davis: University of California, 1992. p. 15-20.

KADER, A. A.; MITCHELL, F. G. Postharvest physiology. In: LARUE, J. H.; JOHNSON, R. S. (Ed.). Peaches, plums and nectarines: growing and handling for fresh market. Davis: University of California, 1989. p. 158-164.

KNEE, M.; LOONEY, N.; HATFILD, S. G. S.; SMITH, S. M. Initiation of rapid ethylene synthesis by apple and pear fruits in relation to storage temperature. Journal of Experimental Botany, Oxford, v. 34, p. 1207-1212, 1983.

LELIÈVRE, J. M.; LATCHÉ, A.; JONES, B.; BOUZAYEN, M.; PECH, J. C. Ethylene and fruit ripening. Physiologia Plantarum, Copenhagen, v. 101, p. 727-739, 1997.

MITCHELL, F. G.; KADER, A. A. Factors affecting deterioration rate. In: LARUE, J. H.; JOHNSON, R. S.
(Ed.). Peaches, plums and nectarines: growing and handling for fresh market. Davis: University of California, 1989a. p. 165-178.

MITCHELL, F. G.; KADER, A. A. Storage. In: LARUE, J. H.; JOHNSON, R. S. (Ed.). Peaches, plums and nectarines: growing and handling for fresh market. Davis: University of California, 1989b. p. 216-222.

MOLLENDORFF, L. J. von; DE VILLIERS, O. T. Physiological changes associated with the development of woolliness in 'Peregrine' peaches during low-temperature storage. The Journal of Horticultural Science, Ashford, v. 63, p. 47-51, 1988.

SISLER, E. C.; SEREK, M. E. Inhibitors of ethylene response in plants at the receptor level: recent developments. Physiologia Plantarum, Copenhagen, v. 100, p. 577-582, 1997.

TAYLOR, M. A. Internal disorders in South African plums. Deciduous Fruit Grower, Bellville, v. 46, p. 328335, 1996.

TRUTER, A. B.; COMBRINK, J. C. Controlled atmosphere storage of South African plums. In: INTERNATIONAL CONTROLLED ATMOSPHERE CONFERENCE, 7., 1997, Davis. Proceedings... Davis: University of California, 1997. v. 3, p. 54-61.

VALERO, D.; SERRANO, M.; MARTINEZ-MADRID, M. C.; RIQUELME, F. Polyamines, ethylene, and physicochemical changes in low-temperature-stored peach (Prunus persica L. cv. Maycrest). Journal of Agricultural and Food Chemistry, Washington, v. 45, p. 3406-3410, 1997.

WANG, C. Y.; ADAMS, D. O. Chilling-induced ethylene production in cucumbers (Cucumis sativus L.). Plant Physiology, Rockville, v. 69, p. 424-427, 1982.

WESCHE-EBELING, P.; ARGAIZ-JAMET, A.; HERNANDEZ-PORRAS, L. G.; LÓPES-MALO, A. Preservation factors and processing effects on anthocyanin pigments in plums. Food Chemistry, Oxford, v. 57, p. 399-403, 1996. 